\section{Added Value of Fecal Calprotectin to Support the Diagnosis of Spondyloarthropathies}

\section{To the Editor:}

We read with interest the article by Kopylov, et al, who reported small bowel inflammation consistent with Crohn disease (CD) in $42.2 \%$ of patients with spondyloarthropathy (SpA) by video capsule endoscopy ${ }^{1}$.

The link between bowel and joint in SpA has been established for several decades. Already in the 1980 s, it was demonstrated that up to $50 \%$ of all patients with SpA have microscopic bowel inflammation, without associated gastrointestinal (GI) symptoms ${ }^{2}$. Calprotectin is a heterodimeric complex of two S100 calcium-binding proteins, myeloid-related protein (MRP)-8 (S100A8) and MRP-14 (S100A9), expressed in granulocytes and monocytes $^{3}$. Fecal calprotectin (FC) is a sensitive and specific biomarker of intestinal inflammation, and quantification of FC is useful for diagnosis and followup of inflammatory bowel diseases (IBD $)^{4,5}$. Also in patients with SpA, FC has been shown to reveal GI inflammation before clinical onset ${ }^{6}$, which was confirmed by Kopylov and colleagues.

In daily practice, the diagnosis of SpA based on the Assessment of Spondyloarthritis international Society (ASAS) criteria is hampered by a relative low sensitivity of $79.5 \%^{7}$. We wondered whether the analysis of FC could add value to the diagnostic process of SpA.

We therefore quantified FC in 99 adult patients who for the first time presented with a clinical suspicion of SpA. Final SpA diagnosis $(n=52)$ was based on expert opinion. Patients were asked to discontinue intake of nonsteroidal antiinflammatory drugs 2 weeks before sample collection, and patients previously diagnosed with IBD were excluded. Three commercially available FC assays (Quantum Blue Calprotectin, Bühlmann; QUANTA Lite Calprotectin Extended Range, Inova Diagnostics; LIAISON Calprotectin, DiaSorin) were performed on each sample.

A summary of the diagnostic performance of the different $\mathrm{FC}$ assays in SpA diagnosis is shown in Table 1. In concordance with the findings of Kopylov, et al, FC levels were significantly higher in the SpA group versus the non-SpA group (Supplementary Figure 1, available from the authors on request). A receiver-operating curve analysis was performed to reveal the diagnostic performance for the different $\mathrm{FC}$ assays for $\mathrm{SpA}$. The area under the curve did not differ significantly among assays, but there was a significant difference in sensitivity and specificity for SpA when the manufacturer's cutoffs were applied. At a cutoff of $98 \%$ specificity for SpA, sensitivities of $13 \%, 21 \%$, and $8 \%$ were obtained for, respectively, the FC assays Quantum Blue Calprotectin, LIAISON Calprotectin, and QUANTA Lite Calprotectin Extended Range. Only for the FC LIAISON Calprotectin assay was a significant OR between the $\mathrm{SpA}$ and non-SpA patient group revealed, increasing the probability for $\mathrm{SpA} 6.8$-fold for a patient with a positive FC test with the LIAISON Calprotectin assay (Table 1). Likelihood ratios [LR; i.e., the likelihood (\%) for patients with SpA divided by the likelihood (\%) for controls] were calculated for different FC test result intervals. The probability of SpA increased with FC, and LR of $0.5,2.0$, and 9.9 for $\mathrm{FC}$ of $\leq 20,21-62,63-200 \mu \mathrm{g} / \mathrm{g}$ were obtained for the LIAISON Calprotectin FC assay. These results show that on the one hand, low FC cannot exclude the diagnosis of SpA (LR of 0.5), and on the other hand, that high FC cannot be used to diagnose SpA (LR of 9.9). Nevertheless, as shown in Table 2, FC improved diagnostic sensitivity if combined with radiology and HLA-B27 analysis in the diagnostic process of patients with suspicion of SpA. For 67 of 99 patients, imaging [radiograph and/or magnetic resonance imaging (MRI)] and HLA-B27 analysis were available and both examinations resulted in an overall sensitivity and specificity for SpA of $67 \%$ and $84 \%$, respectively. Adding FC improved the diagnostic sensitivity to $74 \%$ (Table 2), without reducing specificity. The corresponding LR was 4.6 (indicating a moderate difference in pretest to posttest probability).

Further, FC results could also be used to guide patient management in $\mathrm{SpA}^{8}$. Bowel inflammation seems to be an important prognostic factor in $\mathrm{SpA}$; it was shown to be associated with more extensive bone marrow edema of the sacroiliac joints, a higher risk of progression to ankylosing spondylitis, and a higher risk of developing $\mathrm{CD}^{9}$. Even in the absence of clinical symptoms, endoscopic investigation of patients with elevated FC is advocated. If endoscopy and histologic analysis reveal evidence of active $\mathrm{CD}$, therapeutic management of patients with SpA could be changed, by choosing a treatment option that is effective for both CD and SpA (e.g., adalimumab, infliximab, ustekunimab $)^{10}$. In the study by Kopylov, et al, the finding of $\mathrm{CD}$ led to a change in patient management in $65.2 \%$ of cases $^{1}$. The guidance of SpA management based on FC results is promising and merits further investigation.

FC analysis in combination with imaging and HLA-B27 analysis improves the diagnostic sensitivity in SpA.

\section{ACKNOWLEDGMENT}

We thank DiaSorin and Inova for the donation of the assays. We are very thankful to the laboratory technicians for their efforts.

LIEVE VAN HOOVELS ${ }^{\circ}$, PharmD, Department of Laboratory Medicine, Onze-Lieve-Vrouw Hospital; STEFANIE VAN DEN BREMT ¿ , Medical Laboratory Technician, Department of Laboratory Medicine,

Onze-Lieve-Vrouw Hospital; TOON SCHIEMSKY ${ }^{\circledR}$, MD, Department of

Table 1. Diagnostic performance of different fecal calprotectin assays to support the diagnosis of SpA.

\begin{tabular}{|c|c|c|c|c|c|}
\hline & \multicolumn{2}{|c|}{ Quantum Blue Calprotectin } & LIAISON Calprotectin & \multicolumn{2}{|c|}{$\begin{array}{l}\text { QUANTA Lite Calprotectin } \\
\text { Extended Range }\end{array}$} \\
\hline $\operatorname{AUC}(95 \% \mathrm{CI})$ & $0.658(0$ & $5-0.750)$ & $0.684(0.583-0.774), \mathrm{p}=0.2964 *$ & \multicolumn{2}{|c|}{$0.661(0.559-0.754), p=0.9056^{*}$} \\
\hline Median $(95 \%$ CI $)$ in $\mathrm{SpA}(\mathrm{n}=52)$ & $59.0 \mu \mathrm{g} / \mathrm{g}$ & $9.9-82.0)$ & $25.4 \mu \mathrm{g} / \mathrm{g}(15.8-38.7)$ & \multicolumn{2}{|c|}{$24.6 \mu \mathrm{g} / \mathrm{g}(15.2-32.6)$} \\
\hline Median $(95 \%$ CI $)$ in non-SpA $(n=47)$ & $32 \mu \mathrm{g} / \mathrm{g}(15.0-$ & 4), $p=0.0056^{\S}$ & $11.5 \mu \mathrm{g} / \mathrm{g}(7.9-16.6), \mathrm{p}=0.0017^{\S}$ & \multicolumn{2}{|c|}{$13.0 \mu \mathrm{g} / \mathrm{g}(10.9-15.6) \mathrm{p}=0.0057 \S$} \\
\hline Manufacturer's cutoff & $50 \mu \mathrm{g} / \mathrm{g}$ & $200 \mu \mathrm{g} / \mathrm{g}$ & $50 \mu \mathrm{g} / \mathrm{g}$ & $50 \mu \mathrm{g} / \mathrm{g}$ & $120 \mu \mathrm{g} / \mathrm{g}$ \\
\hline Sensitivity for $\mathrm{SpA}(95 \% \mathrm{CI})$ & $56 \%(41-70)$ & $6 \%(1-16)$ & $29 \%(17-43)$ & $15 \%(7-28)$ & $0 \%(0-7)$ \\
\hline Specificity for $\mathrm{SpA}(95 \% \mathrm{CI})$ & $68 \%(53-81)$ & $98 \%(89-100)$ & $94 \%(83-99), \mathrm{p}<0.0001 * *$ & $\begin{aligned} 96 \% & (86-100) \\
\mathrm{p} & <0.0001 * *\end{aligned}$ & $98 \%(89-100)$ \\
\hline Cutoff at $98 \%$ specificity for $\mathrm{SpA}$ & \multicolumn{2}{|c|}{$157 \mu \mathrm{g} / \mathrm{g}$} & $62 \mu \mathrm{g} / \mathrm{g}$ & \multicolumn{2}{|c|}{$60 \mu \mathrm{g} / \mathrm{g}$} \\
\hline Sensitivity for $\mathrm{SpA}(95 \% \mathrm{CI})$ & \multicolumn{2}{|c|}{$13 \%(6-26)$} & $21 \%(11-35)$ & \multicolumn{2}{|c|}{$8 \%(2-19)$} \\
\hline Likelihood ratio for $\mathrm{SpA}(95 \% \mathrm{CI})$ & \multicolumn{2}{|c|}{$6.3(0.8-49.5)$} & $9.9(1.3-74.1)$ & \multicolumn{2}{|c|}{$3.6(0.4-31.2)$} \\
\hline OR for $\mathrm{SpA}(95 \% \mathrm{CI})$ & \multicolumn{2}{|c|}{$7.2(0.8-60.5), \mathrm{p}=0.1308^{\S \S}$} & $12.3(1.5-99.8), \mathrm{p}=0.018^{\S \S}$ & \multicolumn{2}{|c|}{$3.8(0.4-35.6), \mathrm{p}=0.2372^{\S \S}$} \\
\hline
\end{tabular}

* Evaluation performed versus AUC Quantum Blue Calprotectin using the method of DeLong, et al, in MEDCALC software (version 17.1). ${ }^{\S}$ Mann-Whitney $\mathrm{U}$ test (independent samples). ** McNemar test (paired proportions) versus Quantum Blue Calprotectin. $\$ \S$ OR calculated using the method of Altman, et al, in MEDCALC: if the associated p value is $<0.05$ it can be concluded that the OR is significantly different from 1 and that the odds in 1 group are significantly higher than in the other. SpA: spondyloarthropathies; AUC: area under the curve.

Personal non-commercial use only. The Journal of Rheumatology Copyright (C) 2019. All rights reserved. 
Table 2. Performance of different tests to support the diagnosis of SpA.

\begin{tabular}{|c|c|c|c|c|c|c|}
\hline & $\mathrm{R}, \mathrm{n}=80$ & $\begin{array}{c}\mathrm{R}+\mathrm{HLA}-\mathrm{B} 27 \\
\mathrm{n}=67\end{array}$ & $\begin{array}{c}\mathrm{R}+\mathrm{HLA}-\mathrm{B} 27+ \\
\mathrm{FC}, \mathrm{n}=67\end{array}$ & $\mathrm{FC}, \mathrm{n}=99$ & $\begin{array}{l}\text { HLA-B27 + } \\
\text { FC, } \mathrm{n}=81\end{array}$ & $\mathrm{R}+\mathrm{FC}, \mathrm{n}=80$ \\
\hline Sensitivity $(95 \% \mathrm{CI})$ & $36 \%(24-50)$ & $67 \%(52-79)$ & $\begin{array}{c}74 \%(59-85) \\
\mathrm{p}=0.2482^{*}\end{array}$ & $21 \%(11-35)$ & $71 \%(57-82)$ & $\begin{array}{l}55 \%(41-68) \\
\mathrm{p}=0.0026^{* *}\end{array}$ \\
\hline Specificity $(95 \%$ CI) & $94 \%$ (80-98) & $84 \%(65-94)$ & $84 \%(65-94)$ & $98 \%(89-100)$ & $78 \%(62-88)$ & $88 \%(73-95)$ \\
\hline LR $(95 \% \mathrm{CI})$ & $6.0(1.5-24.1)$ & $4.2(1.7-10.5)$ & $4.6(1.8-11.5)$ & $9.9(1.3-74.1)$ & $3.2(1.7-6.1)$ & $4.6(1.8-11.8)$ \\
\hline OR $(95 \% \mathrm{CI})$ & $8.8(1.9-41.3)$ & $10.5(3.0-36.5)$ & $14.8(4.1-52.8)$ & $12.3(1.5-99.8)$ & $8.6(3.1-23.8)$ & $9.0(2.7-29.6)$ \\
\hline
\end{tabular}

* McNemar test (paired proportions) versus R + HLA-B27.** McNemar test (paired proportions) versus R. With $\mathrm{n}=$ no. patients for which the test(s) was/were performed. SpA: spondyloarthritis; R: radiology (radiograph and/or MRI); FC: fecal calprotectin analysis with LIAISON Calprotectin performed at cutoff of $62 \mu \mathrm{g} / \mathrm{g}$, corresponding to a $98 \%$ specificity for SpA; LR: likelihood ratio; MRI: magnetic resonance imaging.

Laboratory Medicine, Onze-Lieve-Vrouw Hospital; MATHIEU CAUCHIE 10 , PharmD, Department of Laboratory Medicine, Onze-Lieve-Vrouw Hospital; BERT VANDER CRUYSSEN, MD, Department of Rheumatology, Onze-Lieve-Vrouw Hospital; XAVIER BOSSUYT, MD, Department of Laboratory Medicine, University Hospital Leuven, Leuven; KRIS VAN DER STEEN, MD, Department of Clinical Pathology, Onze-Lieve-Vrouw Hospital; MURIEL STUBBE, MD, Department of Rheumatology, Onze-Lieve-Vrouw Hospital, Aalst, Belgium. Address correspondence to L. Van Hoovels, Department of Laboratory Medicine, OLV Hospital Aalst, Moorselbaan 164, 9300 Aalst, Belgium.E-mail: lieve.van.hoovels@olvz-aalst.be

\section{REFERENCES}

1. Kopylov U, Starr M, Watts C, Dionne S, Girardin M, Seidman EG. Detection of Crohn disease in patients with spondyloarthropathy: the SpACE capsule study. J Rheumatol 2018;45:498-505.

2. Cuvelier C, Barbatis C, Mielants H, De Vos M, Roels H, Veys E. Histopathology of intestinal inflammation related to reactive arthritis. Gut 1987;28:394-401.

3. Vogl T, Tenbrock K, Ludwig S, Leukert N, Ehrhardt C, van Zoelen MA, et al. Mrp8 and Mrp14 are endogenous activators of Toll-like receptor 4, promoting lethal, endotoxin-induced shock. Nat Med 2007;13:1042-9.

4. Menees SB, Powell C, Kurlander J, Goel A, Chey WD. A meta-analysis of the utility of C-reactive protein, erythrocyte sedimentation rate, fecal calprotectin, and fecal lactoferrin to exclude inflammatory bowel disease in adults with IBS. Am J Gastroenterol 2015;110:444-54.
5. Lin JF, Chen JM, Zuo JH, Yu A, Xiao ZJ, Deng FH, et al. Meta-analysis: Fecal calprotectin for assessment of inflammatory bowel disease activity. Inflamm Bowel Dis 2014;20:1407-15.

6. Cypers H, Varkas G, Beeckman S, Debusschere K, Vogl T, Roth J, et al. Elevated calprotectin levels reveal bowel inflammation in spondyloarthritis. Ann Rheum Dis 2015;75:1357-62.

7. Rudwaleit M, van der Heijde D, Landewé R, Akkoc N, Brandt J, Chou CT, et al. The assessment of spondyloarthritis international society classification criteria for peripheral spondyloarthritis and for spondyloarthritis in general. Ann Rheum Dis 2011;70:25-31.

8. De Wilde K, Debusschere K, Beeckman S, Jacques P, Elewaut D. Integrating the pathogenesis of spondyloarthritis: Gut and joint united? Curr Opin Rheumatol 2015;27:189-96.

9. Van Praet L, Jans L, Carron P, Jacques P, Glorieus E, Colman R, et al. Degree of bone marrow oedema in sacroiliac joints of patients with axial spondyloarthritis is linked to gut inflammation and male sex: Results from the giant cohort. Ann Rheum Dis 2014;73:1186-9.

10. Braun J, Baraliakos X, Listing J, Davis J, van der Heijde D, Haibel $\mathrm{H}$, et al. Differences in the incidence of flares or new onset of inflammatory bowel diseases in patients with ankylosing spondylitis exposed to therapy with anti-tumor necrosis factor alpha agents. Arthritis Rheum 2007;57:639-47.

J Rheumatol 2019;46:2; doi:10.3899/jrheum.180432 